\title{
Development of Regional Business Ecosystems as an Effective Tool to Counter the COVID-19 Crisis
}

\author{
Submitted 06/06/20, $1^{\text {st }}$ revision 16/07/20, $2^{\text {nd }}$ revision 26/08/20, accepted 15/09/20 \\ Tatiana V. Epifanova ${ }^{1}$, Yana I. Kurinova ${ }^{2}$, Margarita P.Tertishnikova ${ }^{3}$
}

\begin{abstract}
:
Purpose: The purpose of the study is to substantiate the need for the formation of regional entrepreneurial ecosystems that contribute to the sustainability of the development of small and medium-sized businesses in a crisis, as well as to analyze the functions of the structural elements of the ecosystem, ensuring the achievement of efficiency and business performance in the long term.

Design/Methodology/Approach: The methodological basis of the work is a systemic, integrated and dynamic approach to the study of the sustainability of the development of entrepreneurial structures in the conditions of an entrepreneurial ecosystem and the formation of sustainability in entrepreneurial structures in a crisis.

Findings: The core value of creating an entrepreneurial ecosystem lies in the networking between all the building blocks of the ecosystem. Effective network interaction as a result of connecting, integrating, merging the structural elements of the entrepreneurial ecosystem causes a synergistic effect in the implementation of entrepreneurial ideas within the ecosystem and the involvement of new participants in the framework.

Practical Implications: The practice of creating regional business systems will increase the sustainability of business entities due to their natural development, thanks mainly to free access to resources, specialists, technologies and capital. The development of the research can be used in the process of assessing and improving the management systems for the sustainability of development of both an individual small and medium-sized enterprise and business entities as a whole.

Originality/Value: The authors presented a structural diagram of the regional entrepreneurship ecosystem, identified its structural elements. The development of the research can be used in the process of improving management systems for the sustainability of development of regions, business systems and small and medium-sized businesses.
\end{abstract}

Keywords: Small business, regional ecosystem of small business support, Covid-19, crisis.

JEL codes: E27, D63, F63.

Paper type: Research article.

${ }^{1}$ Corresponding author, Rostov State University of Economics, Rostov-on-Don, Russia, ORCID ID 57120161700, profepifanova@gmail.com;

${ }^{2}$ Rostov State University of Economics, Rostov-on-Don, Russia, mpsaratsyn@gmail.com;

${ }^{3}$ Rostov State University of Economics, Rostov-on-Don, Russia, usenyana@yandex.ru; 


\section{Introduction}

The Covid-19 pandemic has had a huge impact on the global economy, the region's economy, and the economies of individual businesses, and this is probably the most significant non-military impact over the past hundred years. In the first quarter of 2020, activity levels fell across all major economies, including China, the Eurozone, the United States, Japan, and Russia, with all countries struggling to fight the COVID19 pandemic with varying degrees of success. Changes in the global economy, transformation of consumer behavior, dependence on the consumption of services have a disproportionately strong impact on small and medium-sized businesses compared to large ones (Noja, 2018; Noja and Cristea, 2018).

Overall, it is estimated that the first quarter of 2020 revealed a sharp decline in global GDP by $11.2 \%$. The most vulnerable there are small and medium-sized entities (SMEs) focused on providing services in the real sector of the economy. A number of following reasons contribute to this: travel restrictions, falling demand and consequent loss of income, credit pressure, severe liquidity shortages, as well as conditions of uncertainty and fear of infection. All these factors affect consumer behavior, reducing consumption costs. SMEs are more susceptible to the impact of the crisis, because as a rule, they do not have large financial reserves, develop through lending and, as a result, have low stability. The greatest problems arose for SMEs operating in the field of restaurant business, tourism, entertainment, provision of consumer services, fashion, etc. Companies that have a higher level of digitalization in comparison with others turned out to be more stable, were able to organize remote work, delivery of goods, and enterprises providing IT services.

Table 1. Decrease in numbers of SMEs and workers employed in regions of Russia (compiled according to the data of the Unified Register of SMEs) (GKS, 2020)

\begin{tabular}{|c|c|c|c|c|c|c|}
\hline \multirow{2}{*}{$\begin{array}{l}\text { Region } \\
\text { (Federal } \\
\text { Districts, FD) }\end{array}$} & \multicolumn{2}{|c|}{ 10.07.2018 } & \multicolumn{2}{|c|}{ 10.07.2019 } & \multicolumn{2}{|c|}{ 10.07.2020 } \\
\hline & $\begin{array}{l}\text { Number } \\
\text { of SMEs }\end{array}$ & $\begin{array}{l}\text { Staff } \\
\text { headcount }\end{array}$ & $\begin{array}{l}\text { Number } \\
\text { of SMEs }\end{array}$ & $\begin{array}{l}\text { Staff } \\
\text { headcount }\end{array}$ & $\begin{array}{l}\text { Number } \\
\text { of SMEs }\end{array}$ & $\begin{array}{l}\text { Staff } \\
\text { headcount }\end{array}$ \\
\hline Volga FD & 1113889 & 3129179 & 1104883 & 3076217 & 1077047 & 2986323 \\
\hline $\begin{array}{l}\text { Northwestern } \\
\text { FD }\end{array}$ & 728834 & 1955477 & 731934 & 1926848 & 712142 & 1867909 \\
\hline Central FD & 1963274 & 5076606 & 1937495 & 5001149 & 1873441 & 4922780 \\
\hline Siberian FD & 720800 & 1863587 & 655067 & 1697860 & 639129 & 1634693 \\
\hline Ural FD & 535383 & 1361760 & 528100 & 1339353 & 518391 & 1301336 \\
\hline $\begin{array}{ll}\text { Far } & \text { Eastern } \\
\text { FD } & \\
\end{array}$ & 268698 & 645632 & 321564 & 769199 & 319278 & 741992 \\
\hline Southern FD & 731108 & 1505369 & 726179 & 1483754 & 705057 & 1455273 \\
\hline $\begin{array}{l}\text { North } \\
\text { Caucasian FD }\end{array}$ & 207164 & 354661 & 206915 & 349717 & 207127 & 358054 \\
\hline Total & 6269150 & 15892271 & 6212137 & 15644097 & 6051612 & 15268360 \\
\hline
\end{tabular}

Source: Own study. 
The main financial problems in the field of small business are caused by the financial expenditures in the absence of activity, namely, the need to pay wages, taxes, social contributions, rent payments, loans to banks and counterparties for supplies, etc. A cash gap has arisen and deepens, leading to bankruptcy a large number of SMEs that are unable to quickly and without loss of quality of work go online, especially in large cities of Russia. In the article, the authors propose a concept for the formation of regional entrepreneurship ecosystems promoting the resilience of small businesses during crises.

\section{Measures to Support Small Businesses in the Current Crisis in Russia and the EU}

The Covid-19 pandemic has had a huge impact on small and medium-sized businesses, many businesses have closed, went bankrupt and left the market, many suffer huge losses, global demand for goods and services has decreased, supply chains have been destroyed, and jobs are being cut (Grima et al., 2020; Khan et al., 2020). The crisis is especially difficult for start-ups. they do not have financial reserves; they work for the future and often cannot use the financial support of the state due to the lack of financial stability and inadequacy of the requirements for preferential lending. State policy in many countries to one degree or another was aimed at supporting small and medium-sized businesses and start-ups.

The measures of state support provided to entrepreneurs during the crisis can be classified into the following categories (Table 2): direct financial support (grants, subsidies) - 1; special measures to support start-ups - 2; tax preferences (tax holidays, reduction of tax rates, deferral of payment for social benefits) -3 ; ensuring liquidity and guarantees for the payment of wages - 4 (concessional lending; subsidizing wage payments; financing of layoffs); special measures to support the self-employed - 5; deferral of debts (loans, rent, utilities) and guaranteeing loans - 6; assistance in finding alternative sales markets -7 ; measures to support remote work and digitalization -8 ; measures to support learning -9 ; legislative measures to change bankruptcy procedures -10 .

Among the analyzed countries (Table 3), Germany, Spain and the United Kingdom became the leaders in providing support to small businesses. In these countries, income from small businesses in the structure of GDP is more than $80 \%$, which indicates an established entrepreneurial ecosystem.

\section{The Concept of Entrepreneurial Ecosystem in the Studies of Foreign and Russian Scientists}

The ecosystem term was first introduced in 1935 by Tansley, A.G. (1935), who designated it as a biological system consisting of a community of living organisms, their habitat and a system of connections for energy exchange between its participants. 
Table 2. Financial policies introduced in Russia and the EU countries

\begin{tabular}{|l|l|l|l|l|l|l|l|l|l|l|l|}
\hline Country & $\mathbf{1}$ & $\mathbf{2}$ & $\mathbf{3}$ & $\mathbf{4}$ & $\mathbf{5}$ & $\mathbf{6}$ & $\mathbf{7}$ & $\mathbf{8}$ & $\mathbf{9}$ & $\mathbf{1 0}$ & Amount \\
\hline Russia & + & + & + & + & & & & + & + & + & 150 Bln.Rub \\
\hline Austria & + & & + & + & + & + & & + & + & & 15 Bln. Eur \\
\hline Great Britain & + & + & + & + & + & + & + & + & & & 30 Bln. Gbr \\
\hline Germany & + & + & + & + & + & + & + & + & + & + & 1,1 Tln. Eur \\
\hline Greece & + & + & + & + & + & + & & & & & $\begin{array}{l}2 \text { Bln. Eur }+1,8 \\
\text { Bln. Special Fund }\end{array}$ \\
\hline Denmark & + & + & + & + & + & + & + & + & + & + & 40 Bln. Dkk \\
\hline Spain & + & + & + & + & + & + & + & + & & & 200 Bln. Eur. \\
\hline Italy & + & + & + & + & + & + & + & + & + & + & 25 Bln. Eur \\
\hline Cyprus & + & + & + & + & + & + & + & + & & & 2 Bln. Eur \\
\hline Lithuania & + & + & + & + & + & + & + & + & & & 5 Bln. Eur \\
\hline Netherlands & + & + & + & + & + & + & + & + & & & 2,5 Bln. Eur \\
\hline Portugal & + & + & + & + & + & + & + & + & & & $\begin{array}{l}60 \\
\text { (Tourism })\end{array}$ \\
\hline Slovenia & + & + & + & + & + & + & + & + & & & 1 Bln. Eur \\
\hline Finland & + & + & + & + & + & + & + & + & + & & 10 Bln. Eur \\
\hline France & + & + & + & + & + & + & + & + & + & + & 45 Bln. Eur \\
\hline
\end{tabular}

Source: Own study.

The use of the term in business and economics was suggested by James Moore (1996), who laid the theoretical foundations for an ecosystem in business. He defined the ecosystem as "dynamic and collaboratively evolving communities, composed of diverse actors who create and receive new content through both interaction and competition." The ecosystem is formed from direct and potential competitors, as well as any other important members of society, also the ecosystem includes suppliers, distribution channels, direct users, etc., the extended ecosystems also include manufacturers, consumers, markets, products, processes, industry associations and departments, risk organizations, authorities and others. The idea was developed in the studies of Teece D.J. (2007), Brown R., Mason C., Mawson S. (2012; 2014). They proposed a description of the key characteristics of entrepreneurial ecosystems, highlighting their openness, competition, dynamic development, diversity, selforganization, and flexibility.

The researchers continued their studies and defined the entrepreneurial ecosystem as a set of interconnected entrepreneurial actors (potential and existing), entrepreneurial organizations (firms, venture capitalists, business angels, banks), institutions (universities, public institutions and financial bodies) and entrepreneurial processes (the number of businesses created, the number of fast-growing firms, the number of serial entrepreneurs, the level of entrepreneurial ambition), which formally and informally unite, mediate and regulate productivity within the local business environment. Jackson D. (2011) noted that the entrepreneurial system includes several interrelated elements (leadership, culture, stock markets, advanced buyers, etc.). And only the whole set of elements, and not just a few separately, promotes the development of entrepreneurship. The combination of all factors, considering their 
interrelation, are the key to success. That is why in countries attempting to use one or two elements of the ecosystem, the expected results were not obtained. To build an effective entrepreneurial ecosystem, six key positions (lessons) should be taken into account: 1) comprehensively develop all elements of the entrepreneurial ecosystem: politics; financial industry; culture; infrastructure to support entrepreneurship; human capital (including education); markets; 2) not to change all the elements of the ecosystem at the same time and at once, you need to start with several, and then change all the others; 3) study the best practices of the whole world, but not imitate the successes of others; 4) build the ecosystem at local levels, only some elements of the entrepreneurial ecosystem (such as politics) should be created at the national level; 5) create independent entrepreneurial teams with special skills and energy to affect stakeholders, while developing all elements of the entrepreneurial ecosystem; 6) apply successful entrepreneurial experiences to support beginners.

In Russia, the concept of entrepreneurial ecosystem has also emerged recently, based on foreign research. Often talking about the entrepreneurial ecosystem, the concept of "innovation cluster" or the institutional environment of entrepreneurship is used (Epifanova et al., 2017a; 2017b). M. Cheryakova and O. Kopachen (2016), researching the conditions for the development of social entrepreneurship in Belarus, emphasize that "the ecosystem favorably affects any entrepreneurial start-ups and supports them in order to provide equal working conditions for entrepreneurs, as well as to guarantee the protection of their rights and a level playing field".

At the same time, they refer to the components of an ecosystem favorable for entrepreneurs, first, a legal and regulatory framework that ensures stability and equal opportunities; second, good educational systems and training opportunities that meet the needs of not only entrepreneurs themselves, but also employees; third, the availability of capital and funding; fourth, a supportive culture that provides a worthy appreciation for the value of entrepreneurship. Russian studies are directed and focused primarily on the Russian Federation and its regions, on certain sectors of the economy, for example, the agro-industrial complex, as well as on various types and areas of entrepreneurial activity, for example, social or youth entrepreneurship.

The most active studies of entrepreneurial ecosystems and their role in accelerating economic development are carried out by Russian scientists in the innovation field. There is an opinion that an innovation or entrepreneurial ecosystem should consist of four main components: ideas (researchers and companies engaged in the development of advanced technologies in the field of specific knowledge), entrepreneurial experience, a developed financing system (a network of venture companies, 'business angel' clubs, etc.) and a community that unites them into a single whole. A concerted effort to advance the commercialization of innovation is essential. I.N. Dubina (2016) defines the concept of a spatial innovation and entrepreneurial ecosystem as a comprehensive open dynamic system, within which a specific institutional environment of an adaptive type is formed, taking into account the strategic objectives of this system and contributing to the processes of expanded reproduction of 
innovations, technologies and human capital. Such a spatial approach, according to the researchers, allows the concept of an ecosystem to be applied to formations of various levels (state, region, cluster, enterprise).

In addition to innovation ecosystems, venture ecosystems are the object of research. As applied to the venture capital industry, it is determined that the venture ecosystem is a set of interrelated elements of the venture business to ensure its self-support and self-development at the expense of private capital, and the factors of the external and internal environment that affect the interaction of participants in the venture capital ecosystem are distinguished.

At the same time, they include the natural, demographic, scientific and technical, economic, social, ecological, political, and international spheres to the factors of the external environment, which are characterized by multivariance, mobility and unpredictability of consequences. The internal environment forms connections and relationships between the participants of the venture ecosystem, because of which the structuring of interactions in the venture capital sector takes place, a special culture is formed. According to the researchers, in Russia the main purpose of the emerging venture capital ecosystem is to support the entrepreneurial environment, which ensures the successful implementation of projects based on a modern partner organizational culture. (Epifanova, 2017b)

Also, in Russia, research is being actively carried out on the ecosystems of universities (Vovchenko and Epifanova, 2019). This is due to the fact that the activation of innovative and entrepreneurial activity is one of the key directions of development of most Russian universities, the basis of which is the formation of an innovative ecosystem of an educational institution. The presence of a formed entrepreneurial ecosystem in the university environment is one of the fundamental conditions for the development of youth entrepreneurship.

At the same time, defining the entrepreneurial ecosystem as a set of conditions that ensure the successful creation and development of firms, emphasizes that the key feature of such an association is the main characteristic of this category - selforganization (Moshkin, 2009).

Summing up the review of the entrepreneurial ecosystem concept, we consider necessary to note the following: first, the ecosystem approach is the theoretical basis of socio-economic research in various fields, including entrepreneurship. Secondly, the entrepreneurial ecosystem is an interdisciplinary concept, which allows the use of various methodological approaches in research, such as evolutionary, institutional, sociocultural, etc. Third, the entrepreneurial ecosystem has a hierarchical structure federal, regional, sectoral, and other levels of its formation and functioning. Fourth, it is necessary to investigate the ecosystems of various types of entrepreneurial activity, including youth, social, innovation, technology, and industry entrepreneurship. 


\section{Structural Organization of the Regional Entrepreneurial Ecosystem}

For the sustainable development of small business on a Russian scale, it makes sense not only to carry out theoretical studies and supplement them with statistical data, but also to provide real government support for the elements of a complex structure of the entrepreneurial ecosystem, as well as introduce digital platforms for the interaction of all structural elements of this complex self-developing structure of the entrepreneurial ecosystem.

In this case, the growth and development of entrepreneurial business structures, including small and medium-sized businesses, will be inevitable. Such an integrated approach will create favourable conditions for the development of small businesses in the regions of Russia, and the introduction of digital platforms will give an impetus to the development of cooperation between all structural elements at the national level (Figure 1).

Figure 1. Entrepreneurial framework

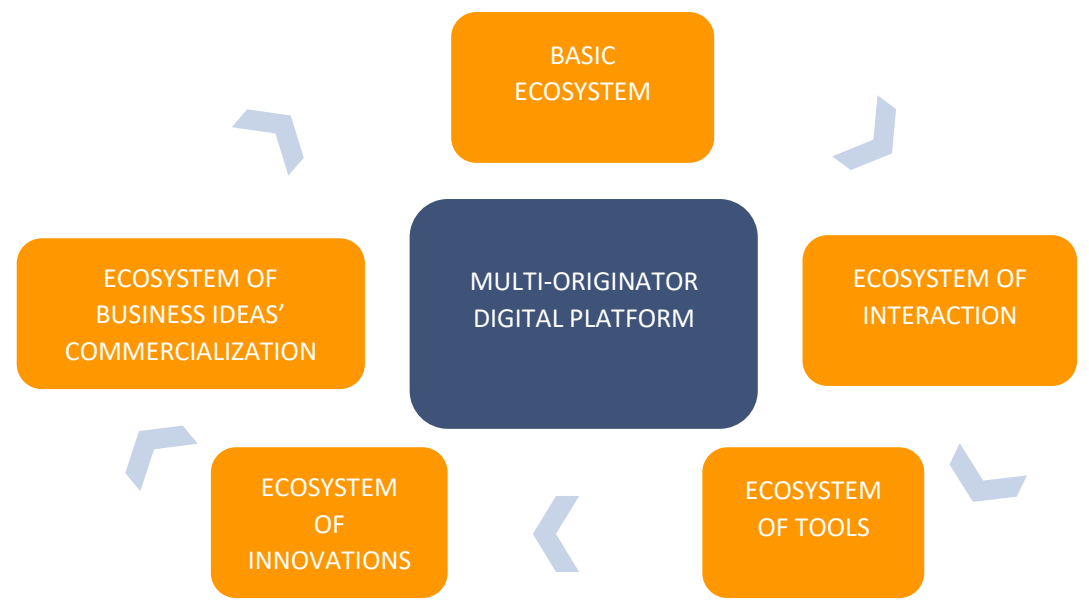

Source: Own study.

The regional entrepreneurial ecosystem is a favourable socio-economic system that promotes the development of entrepreneurship. The basis of a favourable environment is state policy, which is based on legal regulation, state support and the formation of support infrastructure, with universities as centres of innovation forming an entrepreneurial culture of risk tolerant of errors. A large number of business structures within the ecosystem form a request for innovation and implement technology transfer. Student body, youth and schoolchildren are the energy core of the entrepreneurial ecosystem, fuelling it and shaping the entrepreneurial class.

The structure of the entrepreneurial ecosystem developed by the authors includes the following structural elements (Table 3). 


\section{Development of Regional Business Ecosystems as an Effective Tool to Counter the COVID-19 Crisis}

814

Table 3. Elements of entrepreneurial ecosystem

\begin{tabular}{|c|c|c|}
\hline $\begin{array}{c}\text { Basic ecosystem } \\
\text { elements }\end{array}$ & The element & The purpose of element \\
\hline \multirow[t]{6}{*}{ Basic ecosystem } & State policy & $\begin{array}{l}\text { Formation of a favorable business environment, support } \\
\text { programs, a favorable investment climate, competent } \\
\text { customs policy }\end{array}$ \\
\hline & $\begin{array}{l}\text { Entrepreneurial } \\
\text { culture }\end{array}$ & $\begin{array}{l}\text { High social status of an entrepreneur; work for the benefit of } \\
\text { the family, region, country; care for the environment; fair } \\
\text { competition; development of cooperation and interaction } \\
\text { with other entrepreneurs. }\end{array}$ \\
\hline & $\begin{array}{l}\text { Infrastructure } \\
\text { of } \\
\text { entrepreneurial } \\
\text { support }\end{array}$ & $\begin{array}{l}\text { Creates conditions for a massive inflow of investments in } \\
\text { small and medium-sized businesses, ensures the continuous } \\
\text { and seamless activity of entrepreneurial structures, } \\
\text { contributes to the establishment of a normal degree of } \\
\text { coordination of the interests of market entities, which means } \\
\text { the achievement of proportionality in the distribution of } \\
\text { resources and products, the balance of the national economy } \\
\text { as a whole, contributes to the formation of a competitive an } \\
\text { environment that limits the bargaining power of individual } \\
\text { entrepreneurial structures and counteracts monopoly } \\
\text { manifestations. }\end{array}$ \\
\hline & $\begin{array}{l}\text { Educational } \\
\text { entrepreneurial } \\
\text { framework }\end{array}$ & $\begin{array}{l}\text { Commercialization of scientific research through close ties } \\
\text { with the business sector and through its own innovative and } \\
\text { entrepreneurial infrastructure (coworking spaces, "Boiling } \\
\text { Points", business incubators, technology parks, engineering } \\
\text { centers); involvement of undergraduate and graduate } \\
\text { students in entrepreneurial activity; formation of } \\
\text { competencies necessary for engaging in entrepreneurial } \\
\text { activity; development of the institution of mentoring in the } \\
\text { field of entrepreneurship; defense of graduation qualification } \\
\text { works in the field of entrepreneurship; assistance to novice } \\
\text { entrepreneurs in registering the results of intellectual activity; } \\
\text { development of an entrepreneurial culture. }\end{array}$ \\
\hline & $\begin{array}{l}\text { Developed } \\
\text { financial and } \\
\text { banking sector }\end{array}$ & $\begin{array}{l}\text { In crisis conditions and in conditions of development of small } \\
\text { and medium-sized businesses, they provide the support in } \\
\text { borrowed resources; debt refinancing; development of } \\
\text { targeted lending programs for small and medium-sized } \\
\text { businesses; a stable source of investment in the business } \\
\text { sector; redistribution of financial resources within the region } \\
\text { and country; fund financing of the business sector; capital } \\
\text { investments in the modernization of fixed assets of business } \\
\text { structures. }\end{array}$ \\
\hline & $\begin{array}{l}\text { Access to sales } \\
\text { markets }\end{array}$ & $\begin{array}{l}\text { An important part of the ecosystem, if an entrepreneur doesn't } \\
\text { have clients, he doesn't have a business either. Competent } \\
\text { state sales policy; formation of an accessible transport } \\
\text { infrastructure; organization of seamless and conflict-free } \\
\text { access of entrepreneurs to foreign markets; effective legal } \\
\text { regulation of export and import activities; competent customs } \\
\text { policy. }\end{array}$ \\
\hline $\begin{array}{l}\text { Ecosystem } \\
\text { interaction }\end{array}$ & $\begin{array}{l}\text { Chamber of } \\
\text { Commerce and } \\
\text { Industry }\end{array}$ & $\begin{array}{l}\text { Provides aid to Russian organizations and entrepreneurs in } \\
\text { their activities, represents and protects their rights and } \\
\text { interests on issues related to the implementation of economic } \\
\text { activities; organizes interaction between business entities, } \\
\text { their interaction with the state represented by its bodies, as }\end{array}$ \\
\hline
\end{tabular}




\begin{tabular}{|c|c|c|}
\hline & & $\begin{array}{l}\text { well as with social partners; promotes the development of the } \\
\text { export of Russian goods and services; establishes and } \\
\text { develops ties with foreign business and public circles; creates } \\
\text { arbitration institutions (arbitration courts) and other } \\
\text { specialized bodies that facilitate the resolution of business } \\
\text { disputes, and ensures their activities; provides entrepreneurs } \\
\text { with information and consulting services on the organization } \\
\text { and conduct of entrepreneurial activities, market research, } \\
\text { foreign economic and monetary transactions; assists in } \\
\text { patenting intellectual property objects; evidences the } \\
\text { circumstances of force majeure in accordance with the terms } \\
\text { of foreign trade transactions and international treaties of the } \\
\text { Russian Federation, as well as trade and port customs } \\
\text { adopted in the Russian Federation; carries out certification, } \\
\text { examination, quality control, quantity and completeness of } \\
\text { goods; issues international customs documents for temporary } \\
\text { import / export of goods, determines the procedure for their } \\
\text { registration and issuance. }\end{array}$ \\
\hline & $\begin{array}{l}\text { Institutes for } \\
\text { development }\end{array}$ & $\begin{array}{l}\text { Promotes innovation processes; develop innovative } \\
\text { infrastructure using the mechanism of public-private } \\
\text { partnership; finance business projects and co-finance R\&D. }\end{array}$ \\
\hline & Large business & $\begin{array}{l}\text { Participate in cooperation, form groups of small enterprises } \\
\text { that are the part of production and technological chains } \\
\text { (subcontract, outsourcing groups); redistribution of } \\
\text { government orders to support the SME sector. }\end{array}$ \\
\hline & $\begin{array}{l}\text { Cooperation } \\
\text { and } \\
\text { subcontracting } \\
\text { centers }\end{array}$ & $\begin{array}{l}\text { Development of industrial cooperation; organization of } \\
\text { information exchange between enterprises of all forms of } \\
\text { ownership and size; form industrial scientific and technical } \\
\text { clusters; develop interregional ties; accompany and provide } \\
\text { various kinds of informational, logistic, legal support. }\end{array}$ \\
\hline & Export Center & $\begin{array}{l}\text { Provides exporters with financial and non-financial support } \\
\text { tools, including information support, assistance in finding } \\
\text { partners abroad, organizing business missions, assistance in } \\
\text { preparing and collecting the necessary documents, and so on. }\end{array}$ \\
\hline \multirow[t]{3}{*}{$\begin{array}{l}\text { Instrumental } \\
\text { Ecosystem }\end{array}$} & $\begin{array}{l}\text { Multi- } \\
\text { originator } \\
\text { digital platform } \\
\text { to support } \\
\text { SMEs }\end{array}$ & $\begin{array}{l}\text { A key tool in the entrepreneurial ecosystem that enables } \\
\text { digital interaction of all structural elements of the } \\
\text { entrepreneurial ecosystem. }\end{array}$ \\
\hline & $\begin{array}{l}\text { Internet portals } \\
\text { of government } \\
\text { services (State } \\
\text { Services, Tax } \\
\text { Service, } \\
\text { Rosreestr, } \\
\text { Arbitration, } \\
\text { State } \\
\text { Procurements, } \\
\text { etc.) }\end{array}$ & $\begin{array}{l}\text { State information systems providing electronic access for } \\
\text { individuals and legal entities to information and services in } \\
\text { accordance with the capacity of the portal. }\end{array}$ \\
\hline & $\begin{array}{l}\text { Internet } \\
\text { business } \\
\text { platforms ("My } \\
\text { Business", } \\
\text { "Business }\end{array}$ & $\begin{array}{l}\text { Internet platforms providing information and consulting } \\
\text { support to business entities on legal issues, business } \\
\text { organization issues, tax regimes, facilitating the search for } \\
\text { business partners, investors, forms and methods of support. }\end{array}$ \\
\hline
\end{tabular}




\begin{tabular}{|c|c|c|}
\hline & $\begin{array}{l}\text { Navigator", } \\
\text { etc.) }\end{array}$ & \\
\hline \multirow[t]{3}{*}{$\begin{array}{l}\text { Innovation } \\
\text { ecosystem }\end{array}$} & $\begin{array}{l}\text { Universities } \\
\text { and research } \\
\text { centers }\end{array}$ & $\begin{array}{l}\text { Engaged in research and development of innovative } \\
\text { technologies commissioned by business structures. Business } \\
\text { incubators, business accelerators, innovation parks, and } \\
\text { technology parks are developing innovative infrastructure. } \\
\text { Development of student business projects, technology } \\
\text { transfer. }\end{array}$ \\
\hline & $\begin{array}{ll}\text { Industry } & \text { as } \\
\text { customers } & \text { of } \\
\text { innovations } & \\
\end{array}$ & $\begin{array}{l}\text { Form the main demand for innovation, set innovative tasks } \\
\text { for universities. }\end{array}$ \\
\hline & $\begin{array}{l}\text { Innovation } \\
\text { centers }\end{array}$ & $\begin{array}{l}\text { Development, promotion, patenting, licensing and } \\
\text { commercialization of innovations. }\end{array}$ \\
\hline \multirow[t]{5}{*}{$\begin{array}{l}\text { Idea } \\
\text { commercialization } \\
\text { ecosystem }\end{array}$} & $\begin{array}{l}\text { Business } \\
\text { structures }\end{array}$ & $\begin{array}{l}\text { The main partners of universities in the transfer of } \\
\text { technologies, the conclusion of contractual work for the } \\
\text { development of technologies. }\end{array}$ \\
\hline & $\begin{array}{l}\text { State } \\
\text { customers }\end{array}$ & $\begin{array}{l}\text { Funding for innovation, the formation of a demand for } \\
\text { innovation from the state. }\end{array}$ \\
\hline & $\begin{array}{l}\text { Foreign } \\
\text { partners }\end{array}$ & Formation of innovation trends and demand for innovations \\
\hline & $\begin{array}{l}\text { Financial } \\
\text { institutions }\end{array}$ & Funding for innovation \\
\hline & $\begin{array}{l}\text { Business } \\
\text { entities }\end{array}$ & $\begin{array}{l}\text { SMEs, networks, start-ups, self-employed, potential } \\
\text { entrepreneurs. }\end{array}$ \\
\hline
\end{tabular}

Source: Own study.

Entrepreneurial structures within the ecosystem are more resilient in crisis conditions for the following reasons: firstly, within the ecosystem, entrepreneurial structures cooperate within the framework of their business idea, rather than compete; secondly, within the ecosystem, the state contributes to the development of entrepreneurship through the support infrastructure, creates a request on behalf of society for entrepreneurial ideas; thirdly, more and more agents are involved in entrepreneurship, which affects the formation of a favorable image of an entrepreneur in society and contributes to the formation of an entrepreneurial culture; fourthly, the ecosystem is fed with innovative ideas through the educational community; fifth, there are various forms of funding for business ideas in the ecosystem; sixth, the processes of interaction between the business community and the state are being optimized

\section{Conclusions}

Today, an individual company is no longer an independent strategic actor, its success depends on cooperation with other entities in an ecosystem that spans several market sectors. It is difficult for firms to face crises alone, satisfy all customers' requests and experiment with proposals. The key value of creating an entrepreneurial ecosystem lies in the networking between all the structural elements of the ecosystem.

The state ensures a balance, forms a favorable business climate, provides support and forms a demand for entrepreneurship in society, universities create innovations at the request of the market, and participants stop competing and interact on the basis of 
cooperation and mutual assistance. Effective network interaction between all structural elements of the regional entrepreneurial ecosystem as a result of the connection, integration and merger of the structural elements of the entrepreneurial ecosystem determines a synergistic effect in the implementation of entrepreneurial ideas within the ecosystem and the involvement of new participants in the system based on entrepreneurial talent, co-creation, cooperation and fair competition.

\section{References:}

Adner R. 2006. Match Your Innovation Strategy to Your Innovation Ecosystem. Harvard Business Review, 4(84), 98-107.

Aleschenko V.V. 2015. Entrepreneurial networks in the agro-industrial complex: the foundations of formation. Economics and management of innovative processes, projects, programs: proceedings of the International scientific-practical. conf., Omsk, 34-38.

Brown R., Mason C. 2012. Raising the batting average: Re-orientating regional industrial policy to generate more high growth firms. Local Economy, 1(27), 33-49.

Brown, R., Mason C., Mawson, S. 2014. Increasing “The vital 6 percent”: Designing effective public policy to support high growth firms. NESTA Working Paper, 14/01.

Burke, A. J. 2011. How to build an innovation ecosystem? The New York Academy of Sciences Magazine, available online: http://www.nyas.org/publications/Detail.aspx?cid=da1b8e1d-ed2d-4da4826d00c987f63c82.

Cheryakova, M., Kopachen, O. 2016. Social entrepreneurship. Belarusian script. ODB Brussels odb-office, available online: http://www.nadaciapontis.sk.

Dubina, I.N., Kozhevina, O.V., Chub, A.A. 2016. Innovation and entrepreneurial ecosystems as a factor in the sustainability of regional development. Economic analysis: theory and practice, 4(451), 4-19.

Epifanova, T.V., Shatkovskaya, T.V., Romanenko, N.G., Mosienko, T.A., Tkachenko, M. 2017. Legal provision of clustering in Russia as environment for development of innovations. International Journal of Trade and Global Markets (IJTGM), 2/3(10), DOI: 10.1504 / IJTGM.2017.086072

Epifanova, T.V., Skvortsova, T.A., Parshina, E.A. 2017. Influence of clustering on innovational development of business structures in region's economy. International Journal of Trade and Global Markets (IJTGM), 2/3(10), DOI: 10.1504 / IJTGM.2017.086082

GKS. 2020. Official Rosstat Data. Available online: https://www.gks.ru

Grima, S., Dalli Gonzi, R., Thalassinos, I.E. 2020. The Impact of COVID-19 on Malta and its Economy and Sustainable Strategies. Available at SSRN: https://ssrn.com/abstract=3644833 or http://dx.doi.org/10.2139/ssrn.3644833

Jackson, D. J. 2011. What is an Innovation Ecosystem? National Science Foundation, Arlington, VA.

Khan, S., Rabbani, R.M., Thalassinos, I.E., Atif, M. 2020. Corona Virus Pandemic Paving Ways to Next Generation of Learning and Teaching: Futuristic Cloud Based Educational Model. Available at SSRN: https://ssrn.com/abstract=3669832.

Mironova, E.A., Smirnova N.M. 2015. Social entrepreneurship: factors affecting development. Socio-economic transformations and problems, Nizhny Novgorod, NISOTs, 63-80. 
Moore, J. F. 1993. Predators and Prey: A New Ecology of Competition. Harvard Business Review, May / June, 75-86.

Moore, J. F. 1998. The Rise of a New Corporate Form. Washington Quarterly, 1(21), $167-$ 181

Moore, J. F. 2006. Business ecosystems and the view from the firm. The Antitrust Bulletin, $1(51), 31-75$.

Moore, J.F. 1996. The Death of Competition: Leadership \& Strategy in the Age of Business Ecosystems. New York, Harper Business.

Moshkin, I.V. 2009. Entrepreneurial ecosystem of an innovative university. Problems and prospects for the development of entrepreneurship in Russia. North Caucasus Academy of Public Administration.

Noja, G.G., Cristea, M. 2018. Flexicurity Measures as Key Drivers of Economic Growth Empirical Evidence for Europe. Ekonomicky Casopis, 66(7), 719-749.

Noja, G.G. 2018. Flexicurity models and productivity interference in CEE countries: a new approach based on cluster and spatial analysis. Economic research-Ekonomska istraživanja 31(1), 1111-1136.

Tansley, A.G. 1935. The use and abuse of vegetational terms and concepts. Ecology, 16(3), 284-307.

Teece, D.J. 2007. Explicating Dynamic Capabilities, The Nature and Micro-Foundations of (Sustainable) Enterprise Performance. Strategic Management Journal, 13(28), 13191350 .

Vovchenko, N.G., Epifanova, T.V. 2019. On the strategic tasks of a modern university in the field of innovation (on the example of the Rostov State Economic University. Science and Education: Economy and Economics; Entrepreneurship; Law and Management, 8 (111). 